\title{
Un método numérico-estadístico para determinar el volumen elemental representativo (VER) de la pasta de cemento en la medición de la difusividad
}

\section{A numerical-statistical approach to determining the representative elementary volume (REV) of cement paste for measuring diffusivity}

\author{
M. Z. Zhang ${ }^{(*)}$, G. Ye(*), K. van Breugel(*)
}

Recepción/Received: 26-VI-10

Aceptación/Accepted: 28-VII-10

Publicado online/Online publishing: 17-XII-10

RESUMEN

La difusividad del hormigón depende de su microestructura a numerosas escalas, desde nanómetros hasta milímetros, por lo que se precisa de técnicas multiescala para representar este parámetro. Junto con el principio de homogeneización, uno de los métodos multiescala más habituales es el volumen elemental representativo (VER). El objeto de este estudio era establecer un procedimiento que permitiera determinar el VER necesario para calcular la difusividad de la pasta de cemento, basándose en un método numéricoestadístico que consta de tres etapas. Primero, se crearon varias series de microestructuras de pasta de cemento en 3D con HYMOSTRUC3D, un programa que permite crear un modelo de la hidratación y microestructura del cemento. Luego se empleó el método de elementos finitos para simular la difusión de agua tritiada a través de estas microestructuras y se obtuvieron los valores de difusividad efectiva de la pasta de cemento para distintos VER aplicando la ley de Fick. Por último se realizó un análisis estadístico para hallar la fluctuación de la difusividad efectiva en función del volumen de pasta de cemento, a partir de la cual se determinó posteriormente el VER. Se llegó a la conclusión de que el VER para la medición de la difusividad en la pasta de cemento es de $100 \times 100 \times 100 \mathrm{\mu m}^{3}$.

Palabras clave: volumen elemental representativo (VER), pasta de cemento, difusividad, microestructura, HYMOSTRUC3D.

\section{SUMMARY}

Concrete diffusivity is a function of its microstructure on many scales, ranging from nanometres to millimetres. Multi-scale techniques are therefore needed to model this parameter. Representative elementary volume $(R E V)$, in conjunction with the homogenization principle, is one of the most common multi-scale approaches. This study aimed to establish a procedure for establishing the REV required to determine cement paste diffusivity based on a three-step, numerical-statistical approach. First, several series of $3 D$ cement paste microstructures were generated with HYMOSTRUC3D, a cement hydration and microstructure model, for different volumes of cement paste and $w / c$ ratios ranging from 0.30 to 0.60 . Second, the finite element method was used to simulate the diffusion of tritiated water through these microstructures. Effective cement paste diffusivity values for different REVs were obtained by applying Fick's law. Finally, statistical analysis was used to find the fluctuation in effective diffusivity with cement paste volume, from which the REV was then determined. The conclusion drawn was that the REV for measuring diffusivity in cement paste is $100 \times 100 \times 100 \mu \mathrm{m}^{3}$.

Keywords: representative elementary volume (REV), cement paste, diffusivity, microstructure, HYMOSTRUC3D

(*) Delft University, Delft (Holanda).

Persona de contacto/Corresponding author: M.Zhang@tudelft.nl

Trabajo presentado en el 1st CODICE workshop on Multi-scale Modelling and Experiments for Cementitious Materials. Paper presented at 1st CODICE workshop on Multi-scale Modelling and Experiments for Cementitious Materials. 


\section{INTRODUCCIÓN}

La difusión del agua es uno de los principales factores determinantes del deterioro en los materiales derivados del cemento, debido a procesos como el transporte de iones cloruro o la lixiviación (1). En consecuencia, toda evaluación precisa de la vida útil de una estructura de hormigón armado en un entorno determinado, debería tener en cuenta la difusividad del material. Lamentablemente, sigue resultando muy difícil predecir la difusividad del hormigón debido a la complejidad de su microestructura, que depende en gran medida de las proporciones iniciales de la mezcla y de las condiciones de curado a lo largo de su vida útil $(2,3)$. La difusividad del hormigón depende de su microestructura a numerosas escalas, desde nanómetros (los poros) hasta milímetros (los áridos) (4). En los ordenadores actuales no es posible representar de forma simultánea todas estas características estructurales en un único modelo microestructural por sus limitaciones computacionales y de memoria (4). Las técnicas de escalamiento y los métodos multiescala presentan una solución prometedora ante estos impedimentos. El volumen elemental representativo (VER) y el principio de homogeneización se encuentran entre las estrategias multiescala más habituales. En la mesoescala puede considerarse el hormigón o mortero como un material multifase heterogéneo y aleatorio compuesto por pasta de cemento, árido y una zona de transición entre fases (ITZ). En la microescala, la propia pasta de cemento puede verse como un compuesto multifase heterogéneo y aleatorio con poros capilares, partículas de cemento sin hidratar y productos de hidratación. En el método adoptado para el presente estudio, se calculó primero la difusividad a microescala de la pasta de cemento basándose en su microestructura en 3D y luego se emplearon los resultados para determinar la difusividad del mortero u hormigón en la mesoescala.

El volumen elemental representativo de la pasta de cemento es un factor importante no sólo de cara a los experimentos empíricos sino también para el análisis teórico de las propiedades de los materiales. Toda estimación del VER está supeditada a una definición adecuada de la expresión, y son ya varias las definiciones propuestas en la literatura. Hashin (5) propuso la noción de VER para modelizar y estimar las propiedades macroscópicas de un material compuesto heterogéneo. Según este autor, el REV debería cumplir dos requisitos: ser lo bastante amplio para incluir suficiente información sobre la microestructura y mucho menor que la muestra macroscópica. Bear (6) llegó a la conclusión de que el VER de un material compuesto puede considerarse el volumen mínimo en el cual la propiedad del material analizado es equivalente a esa propiedad según la medición real (7-9). Xi (7) puntualizó que, puesto que la relación entre los valores medidos o previstos para la propiedad de un material

\section{INTRODUCTION}

Water diffusion is one of the most important determinants of deterioration in cement-based materials induced by processes such as chloride ion transport or leaching (1). Consequently, any accurate evaluation of the service life of a reinforced concrete structure exposed to a given environment should take the diffusivity of the material into account. Unfortunately, predicting concrete diffusivity remains a challenge because of its complex microstructure, which is largely governed by the initial proportions in the mix and ongoing curing conditions $(2,3)$. Concrete diffusivity is a function of its microstructure on scales ranging from nanometres (pores) to millimetres (aggregate) (4). The simultaneous representation of all these structural features in a single microstructural model is not possible on today's computers due to hardware and software limitations (4). Upscaling techniques and multi-scale methodologies provide a promising solution to these obstacles. Representative elementary volume (REV) and the homogenization principle are among the most common multi-scale strategies. On the mesoscale, concrete/mortar can be regarded to be a random heterogeneous multiphase material containing cement paste, aggregate and an interfacial transition zone (ITZ). On the microscale, cement paste itself can be viewed as a random heterogeneous multiphase composite with capillary pores, unhydrated cement particles and hydration products. In the approach adopted in the present study, microscale cement paste diffusivity was computed first, based on the 3D microstructure of the paste. The results were then used as input to determine mesoscale mortar/concrete diffusivity.

The representative elementary volume of cement paste is an important factor not only for empirical experimentation but also for theoretical analysis of material properties. Any estimate of REV is contingent upon a suitable definition of the term. A number of such definitions have been proposed in the literature. Hashin (5) put forward the notion of REV for modelling and estimating the macroscopic properties of a heterogeneous composite material. According to this author, the REV should meet two requirements: it should be large enough to include sufficient information about the microstructure and should be much smaller than the macroscopic body. Bear (6) concluded that the REV of a composite material can be regarded to be the minimum volume for which the property of the material analyzed is equivalent to that property as effectively measured (79). Xi (7) noted that since the relationship between the measured or predicted value of a property of a given 
concreto, en comparación con el volumen de una muestra de dicho material es una función continua, puede establecerse de manera arbitraria un rango aceptable o crítico de fluctuación para el valor de esa propiedad. Los volúmenes de muestra en los que el valor fluctúa dentro de ese rango pueden considerarse VER aceptables, mientras que debería rechazarse todo volumen en el que el valor fluctúa fuera del rango.

Las mediciones de la difusividad de la pasta de cemento varían según el volumen de la muestra, como se muestra en la Figura 1. Con volúmenes pequeños, los valores empíricos sufren grandes variaciones, mientras que estas fluctuaciones decrecen al aumentar el tamaño de la muestra. Más allá de un cierto umbral o volumen elemental representativo (VER), las oscilaciones pasan a ser adecuadas o despreciables. En las muestras de volumen igual o mayor al del VER, puede considerarse que la pasta de cemento es homogénea y puede emplearse el método del continuo equivalente para evaluar la difusividad efectiva. material vs the volume of a sample of that material is a continuous function, an acceptable or critical range of fluctuation in the value of the property can be arbitrarily established. Sample volumes at which the value fluctuates within that range may be regarded to be acceptable REVs, while any volume at which it fluctuates more widely should be rejected.

Cement paste diffusivity measurements fluctuate depending on sample volume, as shown in Figure 1. At small volumes, the empirical values vary widely. These fluctuations decline with rising sample volume. At a certain threshold or representative elementary volume (REV), they become acceptable or negligible. In samples with a volume larger than or equal to the REV, cement paste can be regarded to be homogeneous and the equivalent continuum approach can be used to evaluate effective diffusivity.

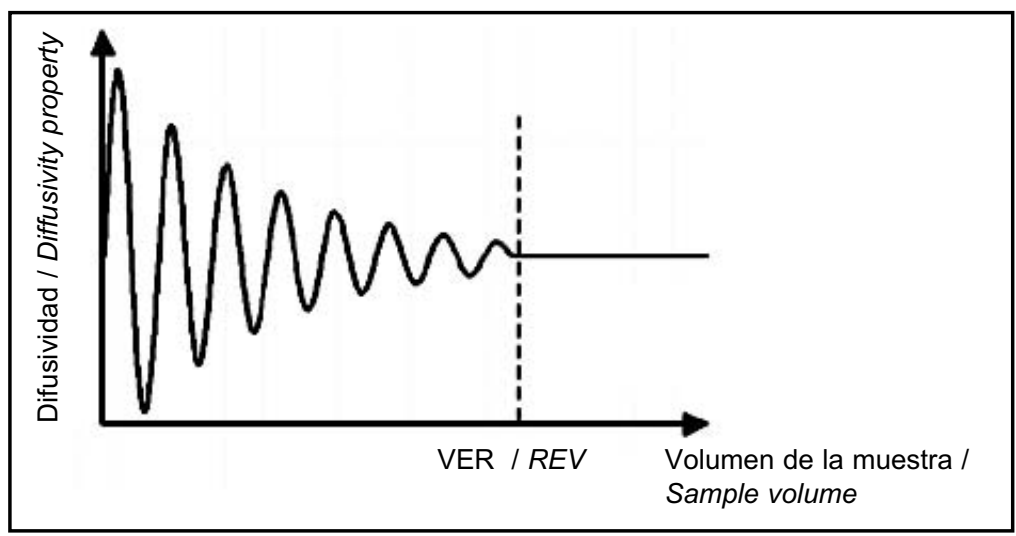

Figura 1. Definición de VER (adaptado de Bear (10)).

Figure 1. Definition of REV (partially modified from Bear (10)).

Dadas las características de la pasta de cemento, la difusividad de este material depende de muchos factores, haciendo que la descripción cuantitativa del VER resulte muy compleja. Por una parte, la pasta de cemento es un material compuesto multifase cuya heterogeneidad microestructural está determinada por numerosos factores, como son la distribución aleatoria de las partículas del cemento, la composición química del cemento, la relación agua-cemento $(\mathrm{a} / \mathrm{c})$ y la edad del material. Por otra parte, desde el punto de vista estadístico, la difusividad de la pasta de cemento debería considerarse como una variable aleatoria, dado el carácter aleatorio de la microestructura no homogénea de este material. La difusividad de la pasta de cemento viene determinada en gran medida por la complejidad de la estructura porosa de la pasta de cemento, es decir, de la distribución de su tamaño de poro, su
Given the characteristics of cement paste, diffusivity in this material depends on many factors, rendering the quantitative description of REV highly complex. On the one hand, cement paste is a multiphase composite material whose heterogeneous microstructure is determined by a number of factors, including the random distribution of cement particles, chemical composition of the cement, water-to-cement $(w / c)$ ratio and material age. On the other hand, statistically speaking, diffusivity in cement paste should be regarded to be a random variable, given the random nature of the non-homogeneous microstructure of this material. Cement paste diffusivity is largely determined by the complexity of cement paste pore structure, i.e., pore size distribution, connectivity and tortuosity. The main purpose of this paper is to establish a procedure for determining the REV for cement paste diffusivity in three 
conectividad y su tortuosidad. El objetivo principal de este trabajo es establecer un procedimiento que permita determinar, en tres etapas, el VER correspondiente a la difusividad de la pasta de cemento. Primero se empleó HYMOSTRUC3D (11-13), para crear microestructuras realistas en 3D de pasta de cemento para distintos volúmenes, con relaciones agua-cemento de entre 0,30 y 0,60 . A continuación se empleó el método de elementos finitos para simular la difusión de agua tritiada a través de las pastas de cemento generadas y se calculó la difusividad efectiva aplicando la ley de Fick. Los valores de difusividad efectiva se representaron luego en función del volumen de pasta de cemento. Por último se llevó a cabo un análisis estadístico para determinar la variación de la difusividad simulada en función del volumen de pasta de cemento. Los resultados de este análisis se emplearon luego para determinar el VER necesario para predecir la transporte de masa mediante difusión. Se eligió agua tritiada como fluido de simulación para este estudio por la insignificante interacción química entre sus moléculas y los productos de la hidratación de la pasta de cemento.

\section{DETERMINACIÓN DEL VER}

\subsection{HYMOSTRUC3D}

HYMOSTRC3D es un modelo tridimensional (3D) para simular el proceso de hidratación del cemento y formación de la microestructura de la pasta de cemento. En estos modelos, el grado de hidratación se simula como una función de la relación a/c, la composición química y la granulometría del cemento y de la temperatura de la reacción. En la Figura 2 se muestra un ejemplo de microestructura simulada. Las partículas esféricas del cemento, que al principio aún no se han hidratado, se sitúan aleatoriamente en el interior de un cuerpo tridimensional (de un volumen determinado) según se muestra en la Figura 2a). En esta primera etapa, las partículas del cemento no se superponen. Durante el proceso de hidratación, los granos de cemento en fase de hidratación se representan en la simulación como esferas en crecimiento. A medida que avanza la hidratación, los granos de cemento van disolviéndose progresivamente y dando lugar a un cascarón poroso de productos de hidratación. Como se muestra en la Figura 2b), los granos crecen hacia fuera. Se desarrollan pequeños clústeres formados por productos de hidratación que rodean los granos de cemento. Se forman grandes clústeres cuando partículas de cemento pequeñas quedan fijadas en el cascarón exterior de otras partículas, lo que fomenta el crecimiento externo de estas últimas. Estas partículas en expansión van creando cada vez más interconexiones entre sí, de tal manera que lo que inicialmente era una suspensión pasa a ser un sólido main steps. First, HYMOSTRUC3D (11-13), was used to generate realistic 3D microstructures of cement paste, assuming different volumes and $\mathrm{w} / \mathrm{c}$ ratios ranging from 0.30 to 0.60 . The finite element method was subsequently used to simulate tritiated water diffusion through the cement pastes generated and the effective diffusivity was calculated with Fick's law. The effective diffusivity values were then plotted against the volume of cement paste. Finally, a statistical analysis was conducted to determine the variation in the simulated cement diffusivity paste with the volume of cement paste. The results of this analysis were used to determine the REV for predicting mass transport by diffusion. In this study, tritiated water was chosen as the fluid for simulation because the chemical interaction between its molecules and cement paste hydrates is negligible.

\section{REV DETERMINATION}

\subsection{HYMOSTRUC3D}

HYMOSTRUC3D is a three-dimensional (3D) model for simulating the cement hydration process and formation of the Portland cement paste microstructure. In these models, the degree of hydration is simulated as a function of the $w / c$ ratio, chemical composition and particle size distribution (PSD) of the cement and the reaction temperature. An example of a simulated microstructure is shown in Figure 2. The spherical, initially unhydrated cement particles are randomly located inside a three dimensional body (of a given volume) as shown in Figure 2a). In this early stage, the cement particles do not overlap. The hydrating cement grains are simulated as growing spheres. As hydration progresses, the cement grains gradually dissolve, generating a porous shell of hydration products. As shown in Figure $2 b$ ), the grains grow outwardly. Small isolated clusters develop, consisting of hydration products around cement grains. Large clusters are formed when small cement particles become embedded in the outer shell of other particles, furthering the outward growth of the latter. These expanding particles progressively become more and more inter-connected and what was initially a suspension becomes a porous solid. Periodic boundary conditions are defined to simulate the location of 
poroso. Se definen condiciones de contorno periódicas para simular la ubicación de las partículas de cemento y de los productos de hidratación con el fin de minimizar los efectos del tamaño finito. cement particles and hydration products to minimize finite size effects.

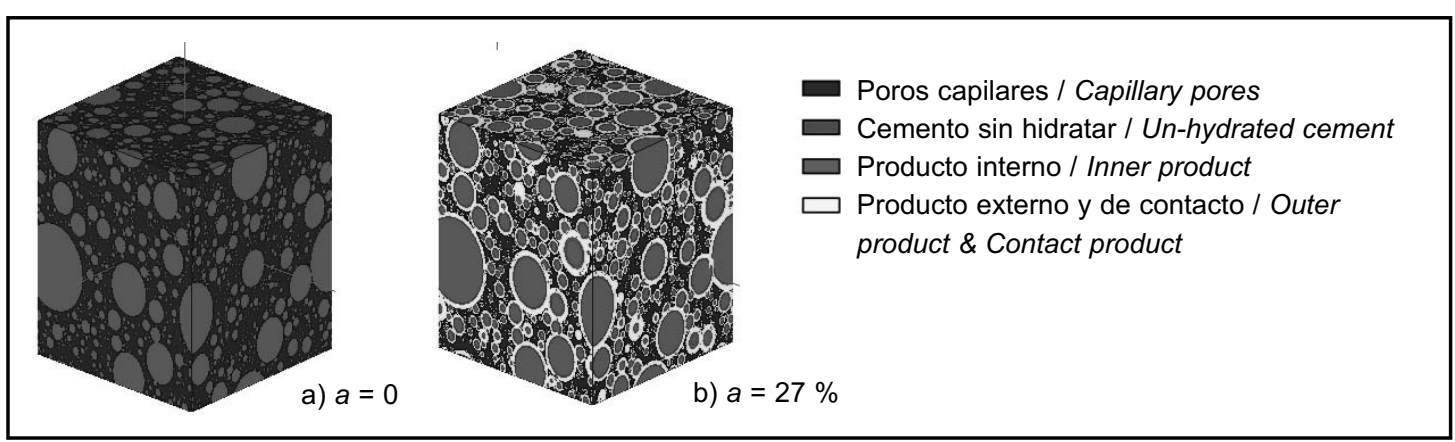

Figura 2. Formación de la microestructura en el modelo HYMOSTRUC3D (11-13). Figure 2. Microstructure formation in the HYMOSTRUC3D model (11-13).

\subsection{Microestructura de las muestras en 3D}

En la Tabla 1 se detallan los principales componentes del cemento Pórtland CEM I 42,5 N, el material empleado en las simulaciones. La Figura 3 muestra la micrografía obtenida mediante microscopía electrónica de barrido (MEB) de las partículas del cemento Pórtland, cuyo diámetro oscilaba entre 0,3-0,5 $\mu \mathrm{m}$ y unos $50 \mu \mathrm{m}$. En las simulaciones, se supuso que el cemento tenía una granulometría continua con un tamaño mínimo de 1 y máximo de $50 \mu \mathrm{m}$, como se muestra en la Figura 4. En el modelo se introdujeron cuatro relaciones a/c distintas $(0,30 ; 0,40 ; 0,50$ y 0,60$)$ con el objeto de evaluar el efecto de ese parámetro en el cálculo del VER.

El sistema poroso capilar constituye un elemento importante de la pasta de cemento endurecida, en especial en lo relativo a las propiedades de transporte del material, siempre y cuando los poros capilares permitan la percolación, es decir, formen una vía de paso continua. La distribución de tamaño de poro de la pasta se determinó mediante imágenes por electrones retrodispersados (BSE). Los resultados de la Figura 5 (13) muestran que el diámetro máximo de los poros capilares era por lo general de unos $30 \mu \mathrm{m}$.

\subsection{D sample microstructure}

The main constituents of CEM I $42.5 \mathrm{~N}$ Portland cement, the material used for the simulations, are listed in Table 1. Figure 3 contains a scanning electron microscope (SEM) image of Portland cement particles, which ranged from 0.3-0.5 $\mu \mathrm{m}$ to about $50 \mu \mathrm{m}$ in diameter. In the simulations, the cement was assumed to have a continuous particle size distribution with a minimum size of 1 and a maximum size of $50 \mu \mathrm{m}$, as shown in Figure 4. Four $\mathrm{w} / \mathrm{c}$ ratios, 0.30, $0.40,0.50$ and 0.60 , were entered into the model for the purposes of evaluating the effect of that parameter on REV determination.

The capillary pore network is an important element in hardened cement paste, particularly as regards the transport properties of the material, providing the capillary pores percolate, i.e., form a continuous pathway. The pore size distributions of the paste were determined with BSE image analysis. The results in Figure 5 (13) show that the maximum diameter of capillary pores was normally about $30 \mu \mathrm{m}$.

Tabla 1 / Table 1

Principales componentes del cemento Pórtland CEM I $42.5 \mathrm{~N}$.

Main constituents of Portland cement CEM I $42.5 \mathrm{~N}$.

\begin{tabular}{|c|c|c|c|c|}
\hline Fases / Phases & $C_{3} S$ & $C_{2} S$ & $C_{3} A$ & $C_{4} A F$ \\
\hline Peso / Weight (\%) & 63.53 & 13 & 8.43 & 9 \\
\hline
\end{tabular}




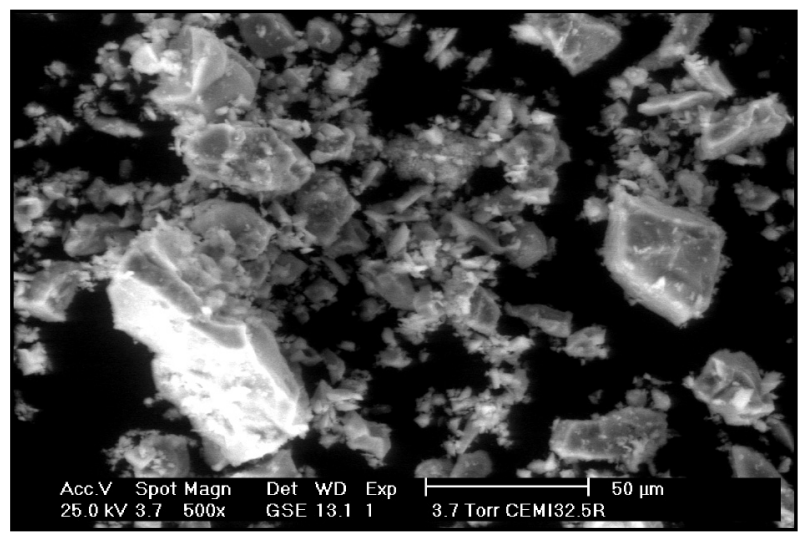

Figura 3. Micrografía de MEB de partículas de cemento Pórtland (CEM I 42.5 N) (13). Figure 3. SEM image of Portland cement particles (CEM I $42.5 \mathrm{~N}$ ) (13).

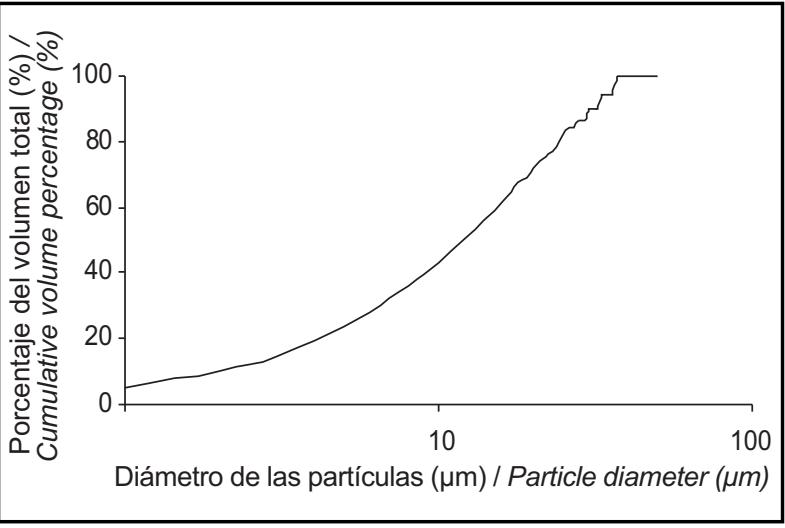

Figura 4. Granulometría del cemento Pórtland empleado en la simulación.

Figure 4. Particle size distribution of the Portland cement used in the simulation.

De conformidad con el análisis anterior y la definición de Hashin (4), el VER debería contener suficiente información sobre la microestructura de la pasta de cemento; de ahí que el tamaño mínimo de muestra que puede tenerse en consideración para calcular el VER deba ser de $50 \mu \mathrm{m}$. Las variaciones en las medidas o lecturas de una determinada propiedad de un material compuesto, se deben principalmente a las diferencias en las fases de los componentes con respecto a la propiedad estudiada y a las anomalías en la configuración de la microestructura local (7). El presente estudio se centra en este segundo aspecto, en especial en la variación del volumen local, que provoca variaciones en la estructura porosa y en la fracción de volumen de cada fase. Teniendo esto en cuenta, se crearon con HYMOSTRUC3D una serie de muestras de pasta de cemento con volúmenes de entre $50 \times 50 \times 50$ y $110 \times 110 \times 110 \mu \mathrm{m}^{3}$. En la Figura 6 se muestran las microestructuras de las muestras creadas con una relación a/c de 0,40 . Para cada tamaño de muestra se crearon cinco realizaciones. A modo de ejemplo, se muestran en la Figura 7 los resultados obtenidos con las muestras de $100 \times 100 \times 100 \mu \mathrm{m}^{3}$, relación $\mathrm{a} / \mathrm{c}=0,40$ y $\mathrm{a}=69 \%$.

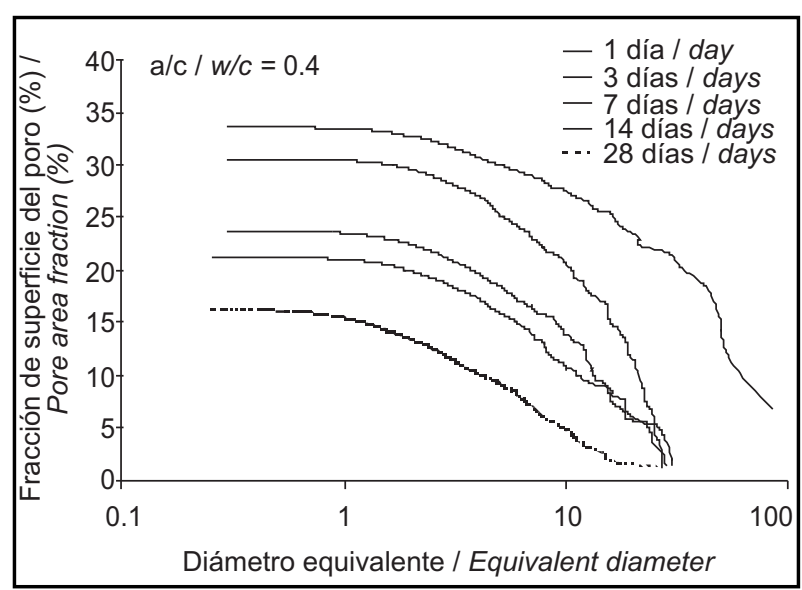

Figura 5. Distribución de tamaño de poro de las muestras en función de la edad de curado $(a / c=0,40)(13)$.

Figure 5. Pore size distribution of the samples by curing age $(w / c=0.40)(13)$.

Pursuant to the above analysis and Hashin's (4) definition, the REV should contain sufficient information on cement paste microstructure. Hence the minimum sample size that may be considered to determine REV should be $50 \mu \mathrm{m}$. The variations in the measurements or readings of a given property of a composite material are due primarily to differences in the constituent phases with respect to the property studied and inconsistencies in the local microstructural configuration (7). The present study focuses on this second aspect, particularly on the variation in local volume, which induces variations in the pore structure and volume fraction of each constituent phase. With this in mind, a series of cement paste samples with volumes ranging from $50 \times 50 \times 50$ to $110 \times 110 \times 110 \mathrm{\mu m}^{3}$ were constructed with HYMOSTRUC3D. The microstructures of the samples generated for a w/c ratio of 0.40 are shown in Figure 6. Five versions were generated for each sample size. By way of example, the results for $100 \times 100 \times 100 \mu \mathrm{m}^{3}$ with $w / c=0.40$ and $a=69 \%$ are shown in Figure 7. 


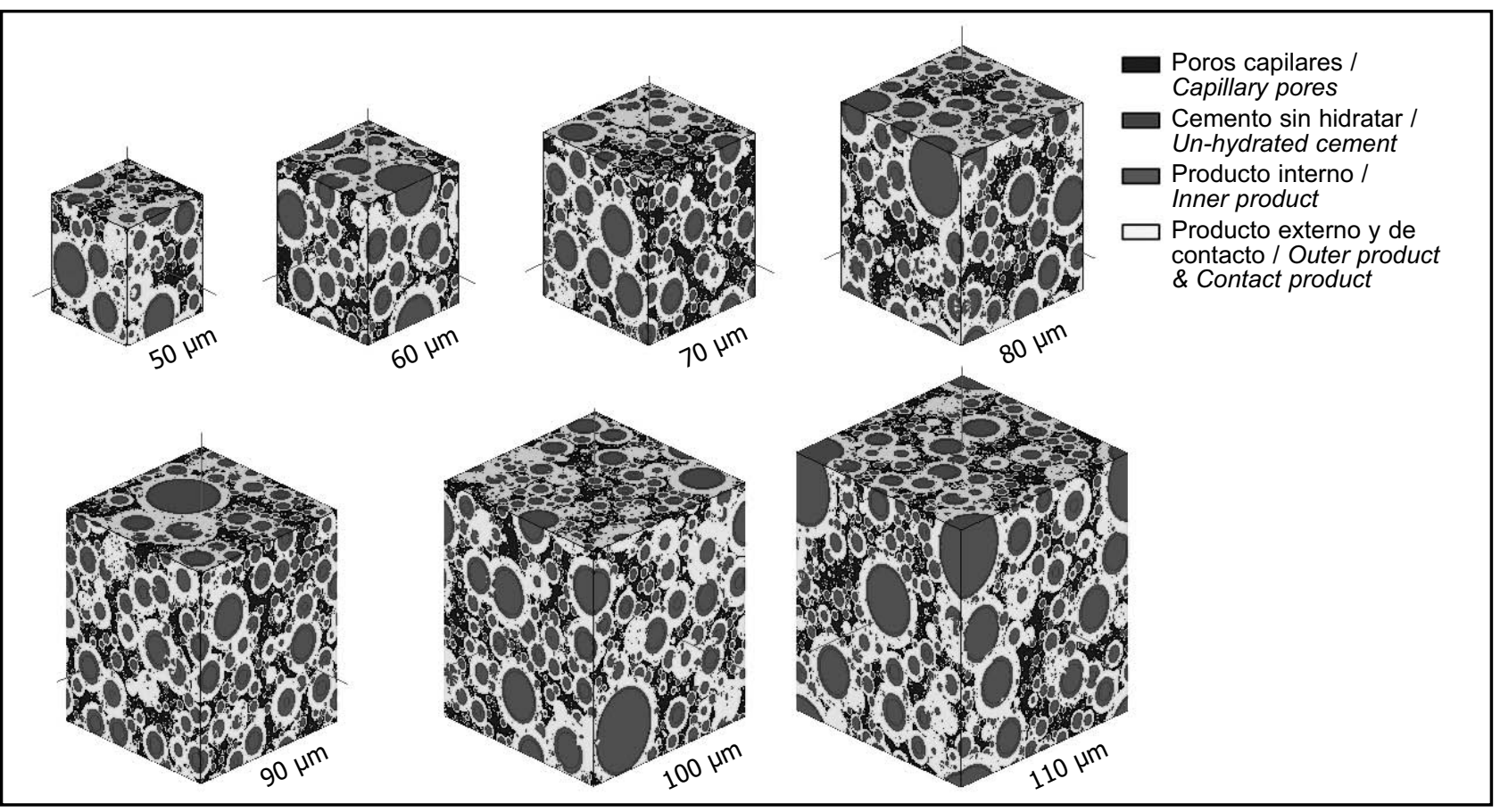

Figura 6. Muestras de entre $50 \times 50 \times 50 \mu \mathrm{m}^{3}$ y $10 \times 110 \times 110 \mu \mathrm{m}^{3}(\mathrm{a} / \mathrm{c}=0,40, \mathrm{a}=69 \%)$.

Figure 6. Samples ranging in size from $50 \times 50 \times 50 \mu \mathrm{m}^{3}$ to $110 \times 110 \times 110 \mu \mathrm{m}^{3}(\mathrm{w} / \mathrm{c}=0.40, a=69 \%)$.

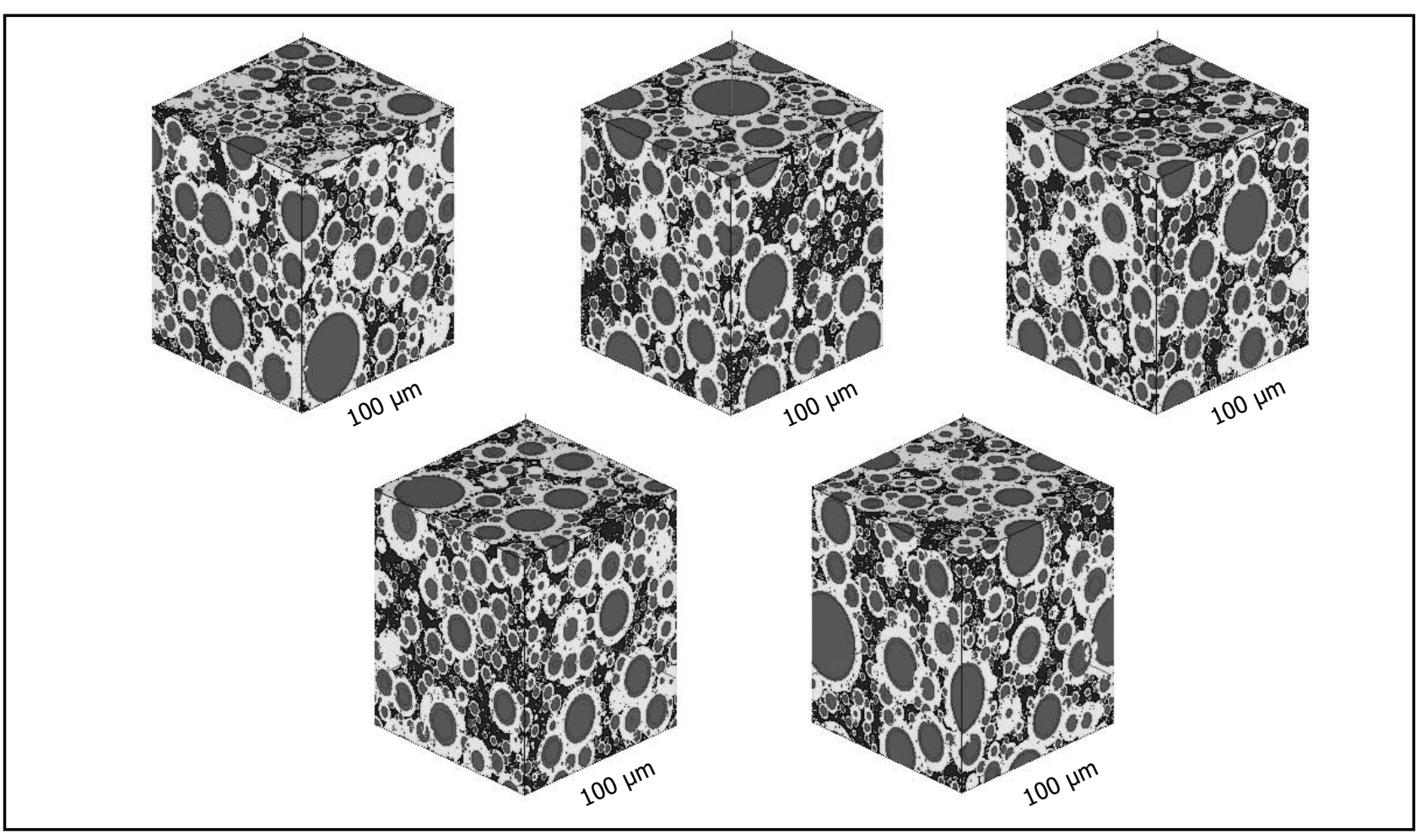

Figura 7. Cinco realizaciones de una muestra de $100 \times 100 \times 100-\mu \mathrm{m}^{3}(a / c=0,40, a=69 \%)$. Figure 7. Five versions of a $100 \times 100 \times 100-\mu \mathrm{m}^{3}$ sample $(\mathrm{w} / \mathrm{c}=0.40, a=69 \%)$

\subsection{Simulación por elementos finitos}

Se aplicó el método de elementos finitos (MEF) para simular la difusión de agua tritiada en la pasta de cemento.

\subsection{Finite element simulation}

The finite element method (FEM) was applied to simulate tritiated water diffusion in cement paste. As noted 
Como se indicó anteriormente, se utilizó HYMOSTRUC3D para recrear el cemento Pórtland como un material compuesto de cinco fases, que son los poros capilares, las partículas de cemento sin hidratar y los productos de hidratación internos, externos y de contacto. La microestructura en 3D creada se relacionó mediante algoritmos a las mallas de elementos finitos correspondientes, previamente ajustadas a una escala adecuada. Se supuso un coeficiente de difusión del agua tritiada a través de los poros capilares $\left(D_{\mathrm{cp}}\right)$ de $2,05 \times 10^{-9} \mathrm{~m}^{2} / \mathrm{s}$ (a $20^{\circ} \mathrm{C}$ ) (14). Siguiendo la propuesta de Garboczi (15), se consideró que el coeficiente de difusión del agua tritiada a través de C-S-H era 1/400 del coeficiente de difusión a través de los poros capilares llenos de agua, y que la fase $\left(\mathrm{Ca}(\mathrm{OH})_{2}\right)$ no era difusiva. Los productos de hidratación que se tomaron en cuenta fueron el C-S-H y el $\left(\mathrm{Ca}(\mathrm{OH})_{2}\right)$. Se supuso que la proporción (en volumen) de cada fase estaba relacionada con el grado de hidratación. Siguiendo el modelo compuesto desarrollado por Christensen (16), puede calcularse el coeficiente de difusión real del agua tritiada a través del producto de hidratación ( $\left(D_{\text {hyd }}\right)$ a partir de la siguiente ecuación [1]: earlier, HYMOSTRUC3D was used to model the Portland cement as a five-phase composite material, consisting of capillary pores, unhydrated cement particles, and inner, outer and contact hydration products. The 3D microstructure generated was then matched algorithmically to the respective finite element meshes, scaled to a suitable mesh size. The diffusion coefficient of tritiated water through the capillary pores $\left(D_{C p}\right)$ was assumed to be $2.05 \times 10^{-9} \mathrm{~m}^{2} / \mathrm{s}$ (at $20^{\circ} \mathrm{C}$ ) (14). Further to Garboczi's (15) proposal, the diffusion coefficient of tritiated water through C-S-H was taken to be 1/400 of the diffusion coefficient through water-filled capillary pores, while the $\mathrm{CH}$ phase was assumed to be nondiffusive. The hydration products considered were $\mathrm{C}-\mathrm{S}-\mathrm{H}$ and $\mathrm{CH}$. The volume proportion of each phase was assumed to be related to the degree of hydration. Further to the composite model developed by Christensen (16), the effective diffusion coefficient of tritiated water through the hydration product $\left(D_{\text {hyd }}\right)$ can be calculated from the following equation [1]:

$$
\frac{D_{\text {hyd }}}{D_{C-S-H}}=1+\frac{f_{c h}}{\left[\left(1-f_{c h}\right) / 3\right]+\left[D_{C-S-H} /\left(D_{C H}-D_{C-S-H}\right)\right]}
$$

Donde $D_{\mathrm{C}-\mathrm{S}-\mathrm{H}}$ y $\mathrm{D}_{\mathrm{CH}}$ son los coeficientes de difusión del agua tritiada a través del C-S-H y el $\left(\mathrm{Ca}(\mathrm{OH})_{2}\right)$, respecti-

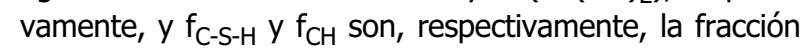
en volumen del C-S- $\mathrm{H}$ y del $\left(\mathrm{Ca}(\mathrm{OH})_{2}\right)$ en el producto de hidratación.

A la vista de la similitud de las densidades de los productos de hidratación internos, externos y de contacto (14$16,17)$, puede suponerse que la difusividad del agua tritiada en estas tres fases es idéntica.

En la Figura 8 se muestra de forma esquemática la difusión simulada del agua tritiada a través de la muestra creada. La concentración de agua tritiada en la superficie de entrada $\left(C_{1}\right)$ se mantuvo constante en un valor de $1 \mathrm{M}$ durante toda la simulación. Asimismo, se definió $C_{1}$ de manera que fuera muy superior a la concentración en la superficie de salida $\left(C_{2}\right)$. En la simulación, se definió $C_{2}$ con valor cero. También se halló el gradiente de concentración de cloruros en el sentido de difusión del agua tritiada a través de la muestra. Se supuso que la concentración inicial en la pasta de cemento era cero. El gradiente de concentración creado dio lugar a un flujo de agua tritiada a través de la muestra. El fluído tardaba un tiempo en llegar a la superficie de salida y alcanzar el estado estacionario. En la Figura 9 puede verse la distribución de la concentración del agua tritiada observada en la pasta de cemento. Se sumó el caudal (Q) en todos los elementos
Where $D_{C-S-H}$ and $D_{C H}$ are the diffusion coefficients of tritiated water through $\mathrm{C}-\mathrm{S}-\mathrm{H}$ and $\mathrm{CH}$, respectively, and $f_{C-S-H}$ and $f_{C H}$ are respectively the volume fraction of $\mathrm{C}-\mathrm{S}-\mathrm{H}$ and $\mathrm{CH}$ in the hydration product.

In light of the similarity of the inner hydration, outer hydration and contact product densities (14-16,17), tritiated water diffusivity in these three phases can be assumed to be identical.

A schematic diagram of simulated tritiated water diffusion through the sample generated is shown in Figure 8. The concentration of tritiated water on inlet surface $\left(C_{1}\right)$ was held constant at a value of $1 \mathrm{M}$ throughout the simulation. Furthermore, $\left(C_{1}\right)$ was defined to be much higher than the outlet surface concentration, $\left(C_{2}\right)$. In the simulation, $C_{2}$ was defined to be zero. The upstream-downstream chloride concentration gradient was also found. The initial concentration in the cement paste was assumed to be zero. The concentration gradient established led to a flux of tritiated water across the sample, with the fluid migrating to the outlet surface and ultimately reaching the steady state. The distribution of the concentration of tritiated water in the cement paste was obtained as shown in Figure 9. The flow, $(Q)$, in all the elements lying on the outlet surface was summed. The flux, (J), across the entire microstructure was 
que se encontraban en la superficie de salida. El flujo (J) a través de toda la microestructura se obtuvo dividiendo el caudal (Q) entre la superficie de la sección (A). Este valor se utilizó posteriormente según la primera ley de Fick para hallar la difusividad efectiva del agua tritiada a través de distintas realizaciones y volúmenes de muestras de pasta de cemento. Este procedimiento se explicaba detalladamente en un trabajo anterior (18). obtained by dividing the flow, $(Q)$, by the area of the cross-section, (A). This value was then used, in accordance with Fick's first law, to find the effective diffusivity of tritiated water through different versions of cement paste samples of varying volume. This procedure is explained in detail in a prior paper (18).

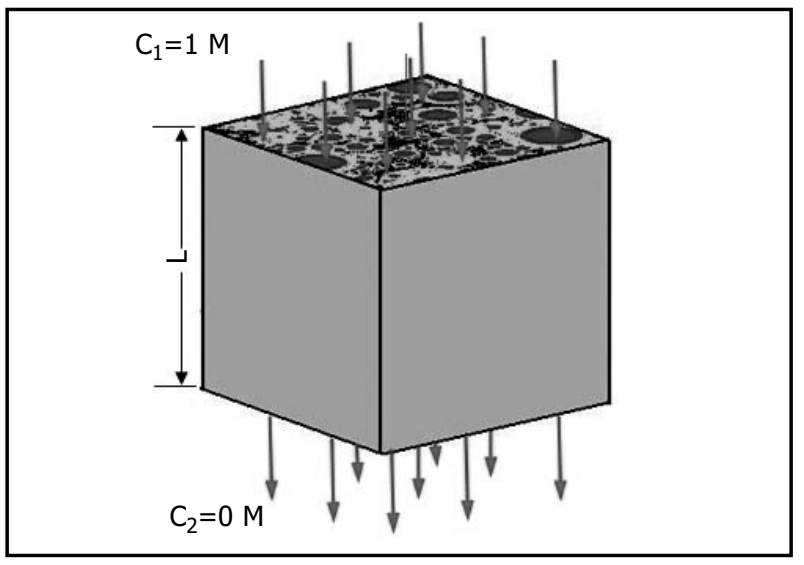

Figura 8. Difusión unidimensional del agua tritiada a través de la pasta de cemento.

Figure 8. One-dimensional diffusion of tritiated water through cement paste.

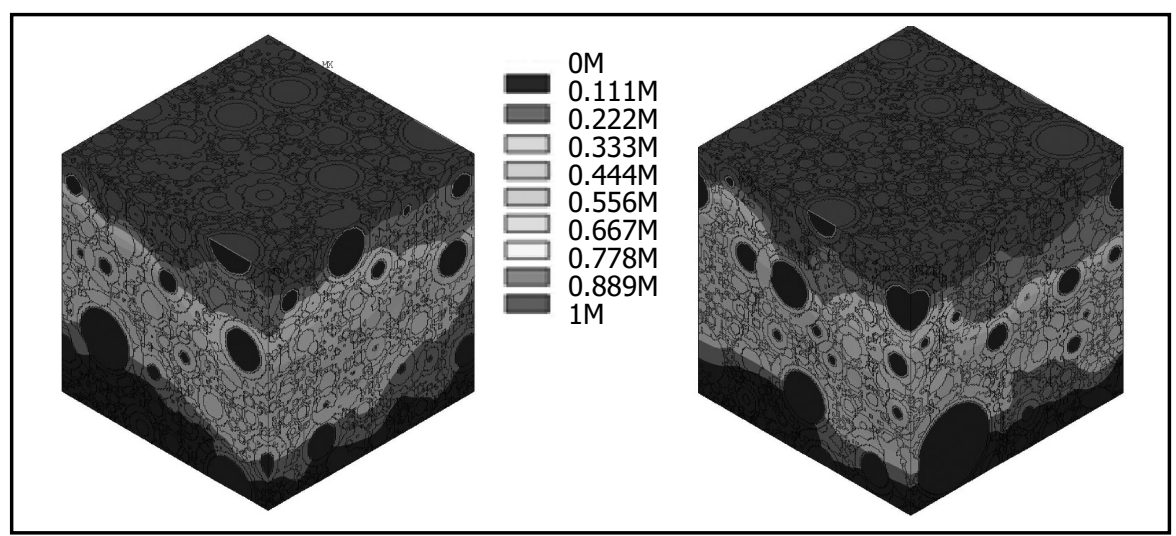

Figura 9. Distribución de la concentración en régimen estacionario de agua tritiada en muestras de $90 \times 90 \times 90 \mu \mathrm{m}^{3}$ y de $100 \times 100 \times 100 \mu \mathrm{m}^{3}$ $(a / c=0,40, a=69 \%)$.

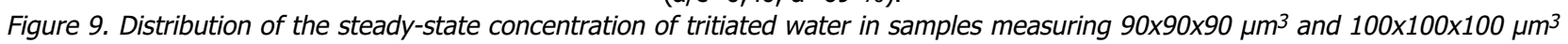
$(w / c=0.40, a=69 \%)$

\subsection{Análisis estadístico}

Se llevaron a cabo una serie de análisis estadísticos para estudiar la fluctuación de la difusividad de la pasta de cemento en muestras de distintos volúmenes. Las media y la desviación típica de la difusividad en las distintas realizaciones $(\mathrm{n})$ de cada muestra, pueden hallarse partiendo de las siguientes fórmulas [2], [3].

\subsection{Statistical analysis}

A series of statistical analyses were conducted to explore the fluctuation of cement paste diffusivity in samples with different volumes. The mean and standard deviation of diffusivity in ( $n$ ) versions of each sample can be found from the following formulas [2], [3]. 


$$
\begin{gathered}
\langle x\rangle=\frac{1}{n} \sum_{i=1}^{n} x_{i} \\
\sigma^{2}=\frac{1}{n-1} \sum_{i=1}^{n}\left(x_{i}-\langle x\rangle\right)^{2}
\end{gathered}
$$

Donde $x_{i}$ es la difusividad en la realización i obtenida a partir de la simulación numérica, $y\langle x\rangle$ y $\sigma^{2}$ son, respectivamente, la media y la desviación típica de los valores de difusividad simulados. El coeficiente de variación $(\varepsilon)$ (según se define en la ecuación número [4]) es un parámetro que puede emplearse para comparar cuantitativamente la difusividad en distintas realizaciones de distintas muestras basándose en sus valores medios.
Where $x_{i}$ is the diffusivity in version $i$ obtained from numerical simulation, and $\langle x\rangle$ and $\sigma^{2}$ are the mean and standard deviation of the diffusivity values simulate, respectively. The variation coefficient $\varepsilon$ (as defined in Eq. [4]), is a parameter that can be used to quantitatively compare diffusivity in different versions of different samples on the grounds of their mean values.

$$
\varepsilon=\frac{\sigma}{\langle x\rangle}
$$

En este método, se utilizó el criterio del chi cuadrado (véase ecuación número [5]) para medir la fluctuación de la difusividad en cada muestra, basándose en la media del valor hallado para las distintas realizaciones. Con este procedimiento se supone que cuanto menor sea el valor de $x^{2}$, más próximo es el volumen de la muestra correspondiente al VER previsto. Según este principio, sólo puede obtenerse el VER real para una muestra de volumen infinito. No obstante, normalmente pueden emplearse muestras de menor tamaño cuando el coeficiente chi cuadrado $\left(\mathrm{x}_{\mathrm{t}}{ }^{2}\right)$ tiene un valor suficientemente bajo.
In this method, the chi-square criterion (see Eq. [5]) was used to measure the fluctuation in diffusivity in each sample based on the mean of the value found for the various versions. This procedure assumes that the smaller the value of $x^{2}$, the closer is the volume of the respective sample to the expected REV. Under this principle, the true REV may only be obtained for a sample with an infinite volume. Nonetheless, smaller size samples can normally be used when the value of the chisquare coefficient, $\left(x_{t}^{2}\right)$ is acceptably low.

$$
\chi^{2}=\sum_{i=1}^{n} \frac{\left(x_{i}-\langle x\rangle\right)^{2}}{\langle x\rangle}
$$

En este trabajo se consideró que 0,103 era un valor aceptable para el coeficiente chi cuadrado $\left(\mathrm{xt}_{\mathrm{t}}{ }^{2}\right)$, para un intervalo de confianza del $95 \%$ y dos grados de libertad. Así pues, se analizaron los coeficientes chi cuadrado de las distintas versiones de cada muestra simulada numéricamente, con el fin de identificar los tamaños de muestra que cumplían con el criterio de aceptabilidad de dicho coeficiente $y$, de este modo, se garantizó la precisión necesaria. Estos resultados pudieron emplearse más tarde para estimar el VER. EI procedimiento para determinar el VER que se describe aquí se muestra en el diagrama de flujo de la Figura 10.
In this paper, 0.103 was regarded to be an acceptable value for the chi-square coefficient, $\left(x_{t}^{2}\right)$, for a $95 \%$ confidence interval and two degrees of freedom. Thus, an analysis of the chi-square coefficients for the various versions of each numerically simulated sample was conducted to identify the sample sizes that met the chisquare coefficient, $x_{t}{ }^{2}$, acceptability criterion and hence ensured the required accuracy. These results could then be used to estimate the REV. The procedure for determining the REV described here is shown in the flow chart in Figure 10. 


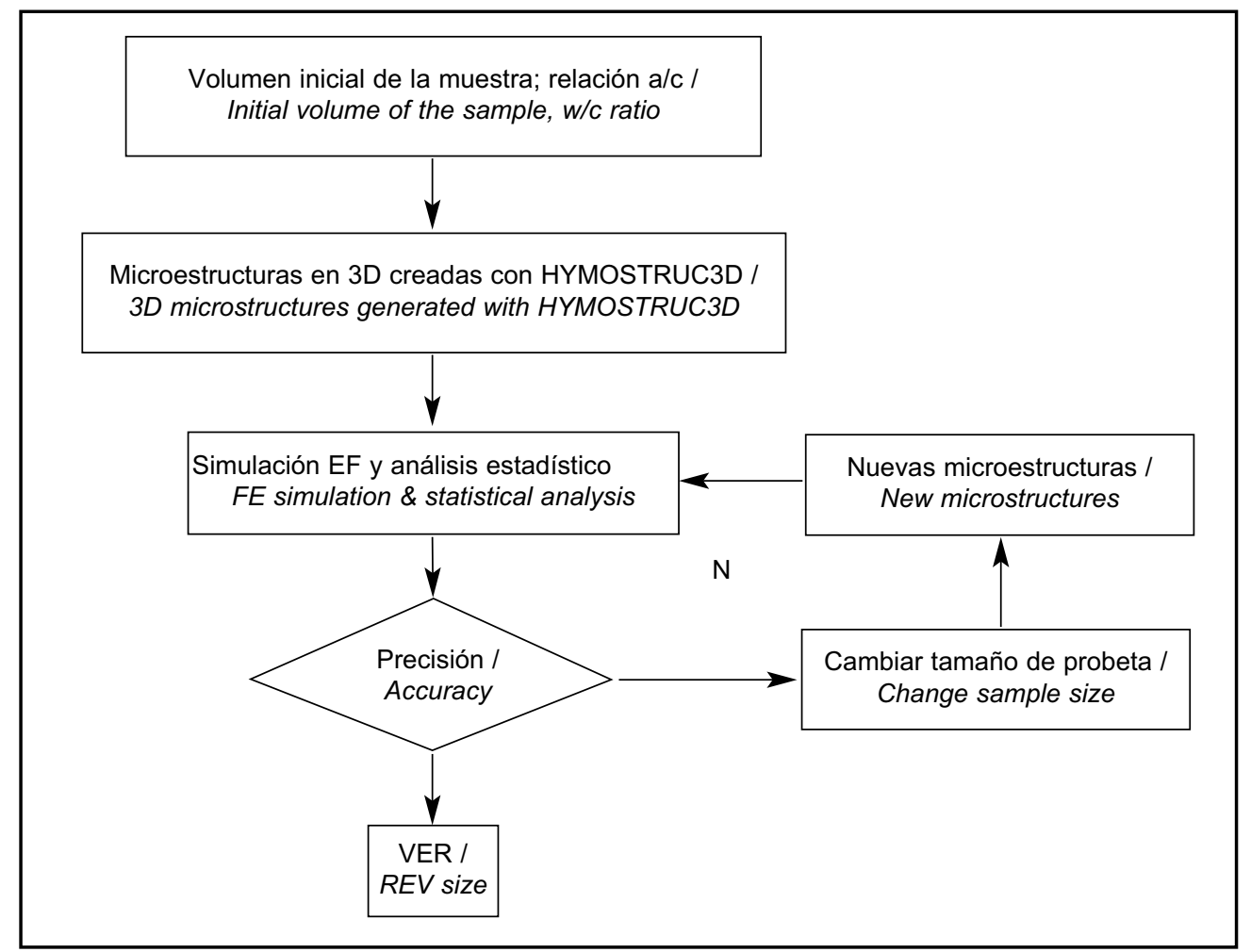

Figura 10. Procedimiento para determinar el VER. Figure 10. Procedure for determining the REV.

\section{RESULTADOS Y DISCUSIÓN}

En las Figuras $11-13$ se muestran, respectivamente, la media $\langle x\rangle$, la desviación típica $\left(\sigma^{2}\right)$ y el coeficiente chi cuadrado $\left(x^{2}\right)$ de la difusividad observada en muestras de distintos tamaños y con distintas relaciones a/c hallados según se describe en el apartado 2 .

De la Figura 11 se desprende que la difusividad efectiva media de las distintas realizaciones de muestras simuladas apenas se vio afectada por el tamaño de la muestra, en especial en aquellas con una relación a/c de 0,40 . Aunque se observó cierta fluctuación en las muestras de volúmenes

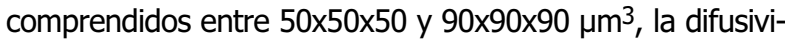
dad tendía a estabilizarse en muestras de volumen superior a $90 \times 90 \times 90 \mu \mathrm{m}^{3}$. Estos resultados se asemejaban mucho a la curva de VER definida por Bear que se representa en la Figura 1. La Figura 11 también muestra que la relación a/c tenía un efecto significativo sobre la difusividad del agua tritiada en la pasta de cemento. Con $\mathrm{a} / \mathrm{c}=0,30$, el sistema poroso fue más denso que con $\mathrm{a} / \mathrm{c}=0,60$ y los poros capilares fueron más tortuosos, lo que dificultaba la formación de una vía de paso continua.

La Figura 12 muestra grandes variaciones en los valores de difusividad de las distintas versiones de muestras inferiores a los $80 \mu \mathrm{m}$. Dichas variaciones se redujeron

\section{RESULTS AND DISCUSSION}

The mean, $\langle x\rangle$, standard deviation, $\left(\sigma^{2}\right)$, and chisquare coefficient $\left(x^{2}\right)$ for diffusivity in samples of different sizes and with different $w / c$ ratios found as described in section 2 are shown in Figures 11-13, respectively.

Further to Figure 11, the mean effective diffusivity for different versions of the simulated samples was scantly affected by sample size, especially for the $w / c=0.40$ samples. While some fluctuation was observed for sample volumes in the $50 \times 50 \times 50$ to $90 \times 90 \times 90 \mu^{3}$ range, diffusivity tended to stabilize in samples of over $90 \times 90 \times 90 \mu^{3}$. These results closely resembled the REV curve defined by Bear reproduced in Figure 1. Figure 11 also shows that the $w / c$ ratio had a significant effect on the diffusivity of tritiated water in cement paste. At $w / c=0.30$, the pore network was denser than at $w / c=0.60$ and the capillary pores were more tortuous, making it more difficult to form a continuous pathway.

Figure 12 shows wide variations in diffusivity values for different versions of samples under $80 \mu \mathrm{m}$, which narrowed in larger samples. Moreover, standard 
en las muestras de mayor tamaño. Además, la desviación típica aumentó al subir las relaciones a/c debido a las diferencias resultantes en la fracción de volumen de cada componente de la pasta de cemento y de la estructura porosa de la muestra. Como cabía esperar, los valores de desviación típica de todas las muestras convergían a medida que aumentaba el tamaño de éstas.

En la Figura 13 se representa el coeficiente chi cuadrado en función del tamaño de la muestra para distintas muestras de pasta de cemento. Como ya se indicó antes, el coeficiente chi cuadrado es el parámetro principal para el cálculo del VER. En la figura se muestra que dicho coeficiente descendió de manera significativa cuando el tamaño de la muestra pasó de 50 a $100 \mu \mathrm{m}$. Además, su valor correspondiente a la muestra de $100 \mu \mathrm{m}$ se encontraba dentro del intervalo de confianza de $95 \%$, es decir, que la muestra de $100 \mu \mathrm{m}$ (y también la de $110 \mu \mathrm{m}$ ) cumplían el criterio del chi cuadrado.

En consonancia con el análisis estadístico anterior de muestras de pasta de cemento de distintos tamaños, y a deviation grew with rising $w / c$ ratios due to the resulting differences in the volume fraction of each cement paste component and sample pore structure. As expected, the standard deviation values for all the samples converged with increasing sample size.

Figure 13 plots the chi-square coefficient against sample size for different samples of cement paste. As noted above, the chi-square coefficient is the primary parameter for determining the REV. The figure shows that the chi-square coefficient declined significantly as the sample size rose from 50 to $100 \mu \mathrm{m}$. Moreover, the chi-square value for the $100 \mu \mathrm{m}$ sample was within the acceptable $95 \%$ confidence interval limits, i.e.,. the 100$\mu \mathrm{m}$ sample (as well as the $110 \mu \mathrm{m}$ sample) met the chisquare criterion.

Further to the above statistical analysis of different size samples of cement paste and in light of the definition of

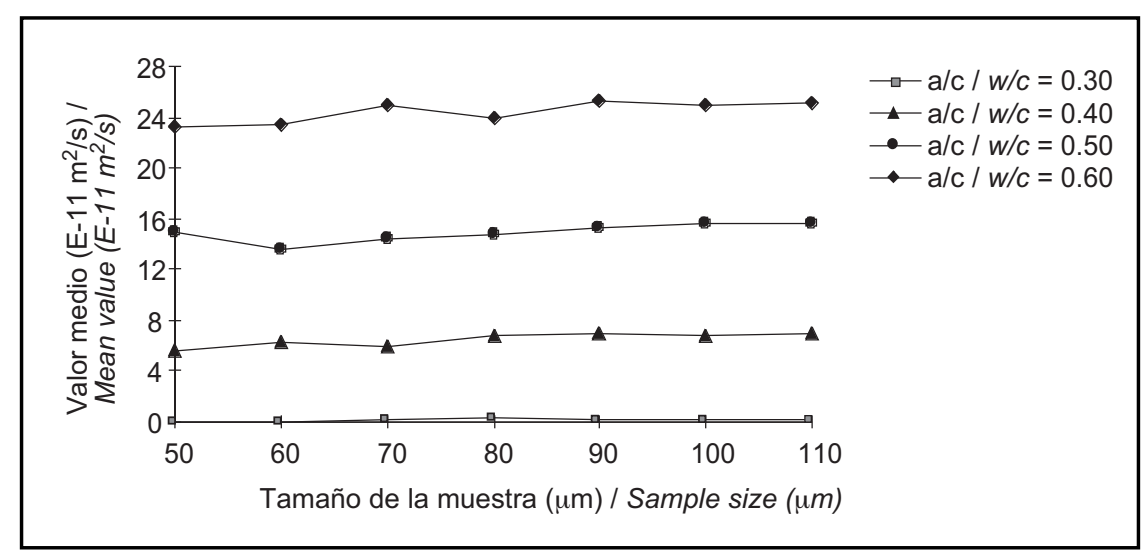

Figura 11. Difusividad media en función del tamaño de la muestra. Figure 11. Mean diffusivity versus sample size.

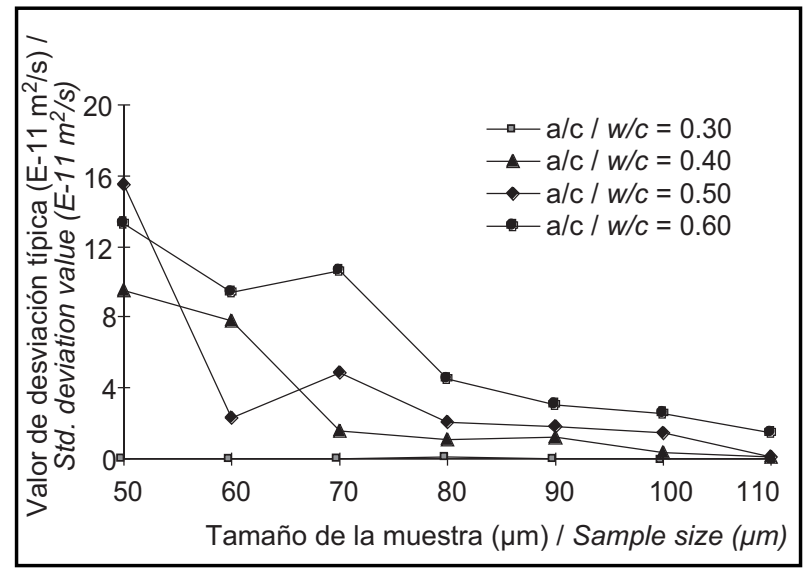

Figura 12. Desviación típica de la difusividad en función del tamaño de la muestra.

Figure 12. Standard deviation for diffusivity versus sample size.

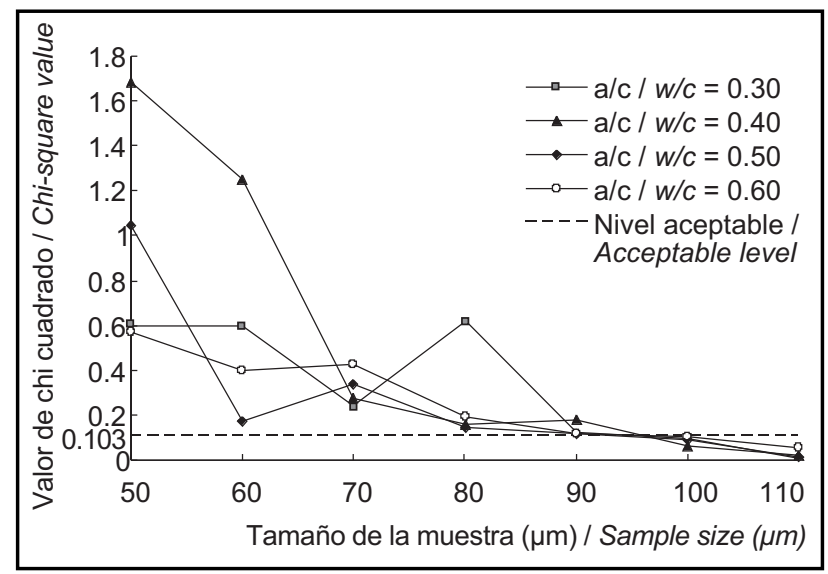

Figura 13. Coeficiente chi cuadrado de la difusividad en función del tamaño de la muestra.

Figure 13. Chi-square coefficient for diffusivity versus sample size. 
la luz de la definición del VER, se concluyó que el valor de este parámetro para la difusividad de pastas de

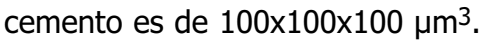

\section{CONCLUSIONES}

El volumen elemental representativo (VER) desempeña una función crucial en la predicción de las propiedades reales de materiales compuestos heterogéneos y aleatorios como el cemento y los productos cementicios. A mesoescala, puede considerarse el hormigón o mortero como un material compuesto que consta de árido, pasta de cemento y una zona de transición entre fases (ITZ). A microescala, puede considerarse la pasta de cemento como un material heterogéneo multifase compuesto por poros capilares, partículas de cemento y productos de hidratación. En los ordenadores actuales, no es posible representar de forma simultánea todas estas características estructurales en un único modelo microestructural, por sus limitaciones de potencia computacional y de memoria. Las técnicas de escalamiento presentan una solución prometedora para relacionar las estructuras de la mesoescala (hormigón), con las de la microescala (poros capilares). La determinación del VER es un paso fundamental en este proceso.

Este artículo describe un procedimiento para determinar el VER basándose en un método numérico-estadístico. Todo el procedimiento puede resumirse en dos etapas: la simulación numérica y el análisis estadístico. En la simulación numérica, se crearon con HYMOSTRUC3D una serie de muestras de pasta de cemento con volúmenes de entre $50 \times 50 \times 50$ y $110 \times 110 \times 110 \mu^{3}$. Las microestructuras creadas se relacionaron posteriormente con mallas de elementos finitos y se ejecutaron simulaciones de elementos finitos. Se analizaron estadísticamente los resultados numéricos obtenidos para distintas realizaciones de muestras de pasta de cemento, con el fin de establecer la difusividad en función del volumen de la muestra de pasta de cemento. Asimismo, se determinó el efecto de la relación a/c sobre el VER introduciendo relaciones de entre 0,30 y 0,60 en el modelo. En total, se crearon 120 muestras con HYMOSTRUC3D.

A partir del análisis numérico-estadístico realizado, se llegó a la conclusión de que el VER para medir la difusividad en la pasta de cemento es de $100 \times 100 \times 100 \mu^{3}$. Con ese tamaño de muestra, el parámetro en cuestión es a la vez lo suficientemente homogéneo y estable desde un punto de vista estadístico como para garantizar la coherencia en el escalamiento de los modelos de difusividad de cara a futuras investigaciones sobre hormigón o mortero. the REV, the value of this parameter for diffusivity in cement paste was concluded to be $100 \times 100 \times 100 \mu^{3}$.

\section{CONCLUSIONS}

Representative elementary volume (REV) plays a central role in predicting the effective properties of random heterogeneous composite materials such as cement and cement products. On the mesoscale, concrete/mortar can be regarded to be a composite material consisting of aggregate, cement paste and an interfacial transition zone. On the microscale, cement paste can be viewed as a multiphase heterogeneous material whose components are capillary pores, cement particles and hydration products. The simultaneous representation of all these structural features in a single microstructural model is not possible on today's computers due to hardware and software limitations. Upscaling techniques provide a promising solution for linking the meso- (concrete) and microscale (capillary pore) structures. The determination of the REV is a critical step in this process.

The present paper describes a procedure to determine the REV based on a numerical-statistical approach. The entire procedure can be summarized in two main steps, i.e., numerical simulation and statistical analysis. In numerical simulation, a series of cement pastes were generated with volumes ranging from $50 \times 50 \times 50 \mu \mathrm{m}^{3}$ to $110 \times 110 \times 110 \mathrm{\mu m}^{3}$ using HYMOSTRUC3D. The microstructures generated were then matched to finite element meshes and finite element simulations were run. The numerical findings for different versions of cement paste samples of each size were analyzed statistically to ascertain diffusivity as a function of cement paste sample volume. The effect of the $w / c$ ratio on the REV was also determined by entering ratios ranging from 0.30 to 0.60 in the model. In all, 120 samples were generated with HYMOSTRUC3D.

The conclusion drawn from the numerical-statistical analysis conducted was that the REV for diffusivity in cement paste is $100 \times 100 \times 100 \mu m^{3}$. At that sample size, the parameter in question is both sufficiently homogeneous and statistically stationary to ensure consistent upscaling in diffusivity modelling for future concrete/mortar research. 


\section{AGRADECIMIENTOS}

El primer autor agradece la financiación parcial de este trabajo por el China Scholarship Council (CSC).

\section{ACKNOWLEDGEMENTS}

This study was partially funded by the China Scholarship Council (CSC). The authors would like to appreciate the editors' contribution.

\section{BIBLIOGRAFÍA / BIBLIOGRAPHY}

(1) Marchand, J.; Gerard, B.: "Microstructure-based models for predicting transport properties", 2nd CANMET/ACI International symposium on Advanced in Concrete Technology, Las Vegas (1995).

(2) Chatterji, S.; Kawamura, M.: "A critical reappraisal of ion diffusion through cement based materials Part I: sample preparation, measurement technique and interpretation of results", Cem. and Concr.e Res., 22 (1992), pp. 525-530.

(3) Bentz, D. P.; Jensen, O. M.; Coats, A. M.; Glasser, F. P.: "Influence of silica fume on diffusivity in cement-based materials I. experimental and computer modeling studies on cement pastes", Cem,t and Concr. Res., 30 (2000), pp. 953-962.

(4) Garboczi, E. J., Bentz, D. P.: "Multi-scale analytical/numerical theory of the diffusivity of concrete", Advn. Cem. Bas. Mat., 8 (1998),

pp. 77-88.

(5) Hashin, Z.: "Analysis of composite materials?a survey", J. Appl. Mech., 50 (1983), pp. 481-505.

(6) Bear, J.: Dynamics of fluids in porous media, Dover, New York, 1988.

(7) Xi, Y.: "Representative volumes of composite materials", Journal of engineering mechanics, 12 (1996), pp. 1159-1167.

(8) Gitman, I. M.: "Representative volumes and multi-scale modeling of quasi-brittle materials", Ph.D. Thesis, Delft University of Technology, Delft (2006).

(9) Nordahl, K.; Ringrose, P. S.: "Indentifying the representative elementary volume for permeability in heterolithic deposits using numerical rock models", Math. Geosci, 40 (2008), pp. 753-771.

(10) Bear, J.: Dynamics of fluids in porous media, Americal Elsevier, New York (1972).

(11) Van Breugel, K.: "Simulation of hydration and formation of structure in hardening cement-based materials", Ph.D. Thesis, Delft University of Technology, Delft (1991).

(12) Koenders, E. A. B.: "Simulation of volume changes in hardening cement-based materials", Ph.D. Thesis, Delft University of Technology, Delft (1997).

(13) Ye, G.: "Experimental study \& numerical simulation of the development of the microstructure and permeability of cementitious materials", Ph.D. Thesis, Delft University of Technology, Delft (2003).

(14) Mills, R.: "Self-diffusion in normal and heavy water in the range 1-45 degree", The Journal of Physical Chemistry, 5 (1973), pp. 685-688.

(15) Garboczi, E.; Bentz, D.: "Computer Simulation of the Diffusivity of Cement Based Materials". Journal of Material Sciences, 27 (1992), pp. 2083-2092.

(16) Christensen, R. M.: "Mechanics of Composite Materials". Wiley Interscience, New York (1979).

(17) Jennings, H. M.: "Colloid model of C-S-H and implications to the problem of creep and shrinkage", Materials and Structures, 37 (2004), pp. 59-69.

(18) Zhang, M. Z; Ye, G; van Breugel, K.: "Microstructure-based modelling of water diffusivity in cement paste", Construction and Building Materials (accepted). 